\section{India may retaliate over US expulsion of its scientists}

[NEW DELHI] The Indian government has asked its research community to show restraint while it considers how to respond to the expulsion of seven Indian scientists from the United States.

Up to 75 more may be asked to leave under the new US policy of expelling Indian and Pakistani scientists working on US government-funded projects or in institutions if they are affiliated to their countries' nuclear organizations, even if the scientists themselves work in non-nuclear fields.

The US action, intended to punish India for having conducted nuclear tests, has drawn strong protests. India's science minister, Murli Manohar Joshi, said India "expected more mature behaviour from the US administration".

In a statement, he accused Washington of reducing science and technology "to a ball game for serving partisan interests", and hoped that the US and international scientific communities would make concerted efforts to end such "discrimination".

The expulsions also prompted condemnation from the upper house of the Indian parliament, with some members urging prime minister Atal Behari Vajpayee to retaliate by expelling US scientists in India. But India's science secretary, Valangiman Ramamurthi, says: "We do not want to take this battle to the street corner. We want to behave in a dignified and mature way."

Nonetheless, India's science ministry is looking at options to hit back at the United States. Possible targets include cancelling an agreement with the US space agency NASA to share data obtained from its Insat geostationary satellites (see Nature 391, 109; 1998). Also in jeopardy is an agreement with India's Department of Biotechnology under which US companies were hoping to test new male contraceptive drugs.

A US State Department official describes the prospect of retaliation as "regrettable", but adds that it will not affect US government policy. The seven expelled scientists, he says, are all affiliated to Indian atomic energy- and defence-related research organizations. They were working on research projects at the National Institute of Standards and Technology in Maryland.

They have been asked to leave by the end of the month. Two have already left, however, and one is planning legal action against the US university which he says gave him 24 hours to leave the country with his family.

"The way Indian scientists are being treated as bonded labour is an insult to the US scientific community and its academic freedom," says Ramamurthi. K. S. Jayaraman

\title{
Xenotransplant experts face good and bad news
}

[LONDON] An international panel of scientists is due to meet in London today (6 August) to discuss the results of organtransplant studies. These are likely to send mixed signals on whether it is safe to transplant animal organs into humans.

The meeting is a closed one-day workshop organized by the UK Xenotransplantation Interim Regulatory Authority (UKXIRA). The topics for discussion are expected to include "promising results" from an industry-funded study of 150 patients already treated with living pig tissue, such as islet cells for the treatment of diabetes.

But academic researchers from Britain are expected to announce the results of a study showing that a variant of a pig retrovirus previously thought to be safe can infect human cells under laboratory conditions.

The meeting comes a week after the British government released its guidelines on regulating xenotransplants. These say that the Secretary of State for Health will decide on each application for a human trial of an organ transplant, based on advice from UKXIRA. The authority, in turn, will be supported by a number of expert assessors.

The welfare of animals bred for human transplants will be included in UKXIRA's terms of reference. And the government's advisory committee on dangerous pathogens is to set up a working group to investigate the risks of infection from different forms of xenotransplant therapy. The guidelines endorse a Home Office ban on the use of primates as organ donors.

The move has been welcomed by companies developing animal organs for human transplants, as it allows them to apply to proceed with human trials. A statement from Imutran, the xenotransplant arm of the life sciences company Novartis, described the announcement as "an important step".

Today's meeting was arranged to discuss the latest research on whether pig viruses can transfer into humans. This is one of the main concerns holding up regulatory approval for animal-to-human transplants.

Researchers have been able to eliminate most non-inherited viruses from human transplant organs bred in pigs. But there are four known variants of a pig virus - the porcine endogenous retrovirus (PoERV) found in the chromosomes of pigs that cannot be eliminated.

Two of the four variants of PoERV are known to be capable of crossing the species barrier and infecting human cells. But today's meeting is expected to hear of a third virus, not found in all pigs, that has been

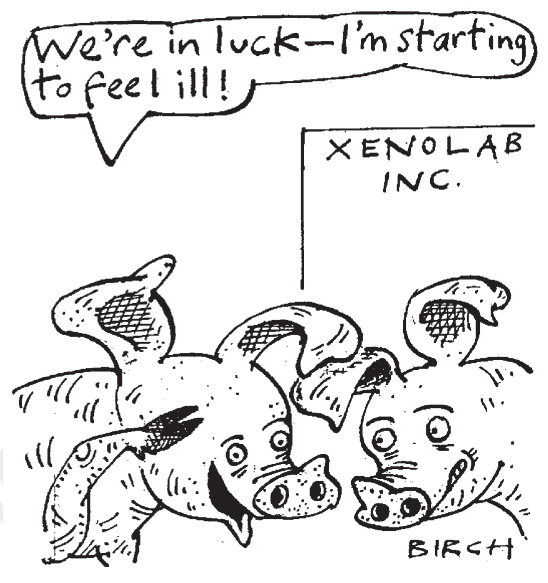

found to infect a human cell line under laboratory conditions.

Better news for proponents of xenotransplants is expected from a study organized by Imutran of 150 patients who have been treated with living pig tissue. Samples were collected from patients worldwide. Each was analysed twice - by a laboratory in the United Kingdom and by one in the United States - to see if the pig retrovirus had transferred to any patient.

"The results are very interesting," says David Onions, an adviser to Imutran and director of the Glasgow-based laboratory Q1 Biotech, which analysed one set of samples. Onions says he cannot provide further details until the data are published. But he describes them as "encouraging".

Imutran is relying heavily on the results of this study for its plans to develop xenotransplant organs. The next step, according to a company statement, is to attach transgenic livers outside the body of a small number of patients waiting for a liver transplant, enabling the pig livers to work along the lines of a liver dialysis machine.

The pig liver would work for about 48 hours, allowing doctors extra time to find a suitable human liver for transplantation. "This study will then be reviewed to assess the safety and efficacy of the transgenic organs," says the statement.

Imutran is not the first to use such a technique. An analysis by the Institute of Cancer Research in London, of two cases of pig kidneys similarly attached to patients, has been accepted for publication in a medical journal.

Meanwhile, the US Food and Drug Administration is due to publish guidelines on xenotransplantation this autumn. These are expected to advocate long-term monitoring of recipients and a possible ban on the use of non-human primates (see Nature Medicine 4, 876; 1998).

EhsanMasood 